\title{
Los métodos gravitacionales como herramienta para el cálculo de las emisiones de gases de efecto invernadero derivadas del tráfico rodado en la planificación urbana
}

\section{Gravity methods as a tool to calculate greenhouse gas emissions from road traffic in urban planning}

\author{
Sergio Zubelzu Mínguez*1 , Alfonso López Díaz*, Miguel Ángel Gutiérrez García*, Fernando Blanco Silva** \\ * Universidad Católica de Ávila. ESPAÑA \\ ** Universidad de Santiago de Compostela. ESPAÑA \\ Fecha de recepción: 01/ 02/ 2011 \\ Fecha de aceptación: 20/ 06/ 2011 \\ PAG. 187 - 207
}

\begin{abstract}
Resumen
El presente artículo propone una metodología para la estimación de las emisiones de gases de efecto invernadero que se producen consecuencia del tráfico rodado en las ciudades. El método adopta como punto de partida la información relativa a los núcleos existentes en el término y los crecimientos previstos por la actividad urbanística estimando el tráfico que se prevé generarán ambos mediante un modelo gravitacional. Este modelo permite identificar los recorridos que presumiblemente seguirán los vehículos y así calcular sus emisiones de gases de efecto invernadero. De esta forma se dispone de información respecto de la huella de carbono pueden incluirse medidas correctoras o compensatorias de las emisiones en la fase de diseño urbanístico.
\end{abstract}

Palabras Clave: Gases de efecto invernadero, modelo gravitacional, diseño urbanístico, planeamiento urbano, tráfico rodado

Abstract

This paper proposes a methodology for estimating greenhouse gas emissions from road traffic. The method uses information about the cities and their growth estimates in order to model traffic by using a gravity model. These kind of mathematical models allow study the number of trips "originated in" or "destined for" a particular area and distribute them to calculate the greenhouse gases emissions from these trips. In this way the information regarding these emissions can be used in urban planning phase and preventive and compensatory measures can be included in these processes.

Keywords: Greenhouse gas, gravity model, urban design, urban planning, road traffic

\section{Introducción}

La aprobación del Protocolo de Kyoto (1997) impuso la necesidad de compensar las emisiones de Gases de Efecto Invernadero (GEls) generados en determinados sectores de actividad comúnmente denominados sectores regulados.

Pero, más allá de estos sectores, existe un interés creciente en conocer, incluso compensar, los GEIs generados en otros ámbitos distintos de los regulados por el Protocolo de Kyoto.

Dentro de estos otros ámbitos, puede considerarse el tráfico rodado como uno de los más significativos debido a su carácter transversal, a su relación de dependencia con la totalidad de la economía y a la magnitud agregada de movimientos de los que depende el funcionamiento diario de las ciudades.

\section{Introduction}

Kyoto Protocol adoption (1997) imposed the need to compensating emissions of greenhouse gases (GHGs) generated in some sectors of activity commonly known as regulated sectors.

But beyond these sectors, there is growing interest in knowing and even in compensating the greenhouse gases generated in other areas, different than those ruled by Kyoto Protocol.

Some of these other areas is traffic, which can be considered as one of the most significant ones because of its horizontal character, its particular relationship with the entire economy and the aggregate magnitude of movements of which depends the daily functioning of the cities .

\footnotetext{
1 Autor de correspondencia / Corresponding author:
}

E-mail: Sergio.zubelzu@ucavila.es 
Esta relevancia del tráfico rodado está justificada por múltiples razones entre las que pueden incluirse las relacionadas con el diseño urbanístico. En la actualidad la dinámica de planeamiento urbano se orienta hacia tipologías edificatorias unifamiliares aisladas, intensivas en cuanto a la cantidad de suelo necesario y, por tanto, dependientes del transporte mediante tráfico rodado privado, mayoritariamente (Correa, 2010). En este contexto, resultaría de utilidad disponer de un mecanismo que permita conocer y compensar las emisiones de GEIs debidas al tráfico rodado en las ciudades: Los requisitos impuestos a este mecanismo y que constituyen los objetivos del presente trabajo son los siguientes:

1. Proponer un método que contribuya a la identificación del responsable de la emisión del GEI de manera que pueda imputársele el coste derivado de su compensación.

2. El método debe integrarse en una fase preliminar en la que sea posible la compensación, al menos teórica, de las emisiones mediante los propios instrumentos del diseño urbano.

3. El método debe proporcionar un mecanismo útil para la cuantificación de la fuente de la generación de los GEI debidos al tráfico rodado.

4. Por último, debe proporcionar resultados comparables con los datos reales de generación que se midiesen una vez ejecutados los desarrollos urbanísticos.

En el presente trabajo se propondrá una metodología para la determinación de las emisiones de GEls basada en las técnicas de distribución espacial del tráfico y que aporten soluciones a las limitaciones anteriores. Para exponer la aplicación práctica del modelo propuesto se analizará el caso de Villaluenga de La Sagra, un municipio de $\mathbf{3 . 0 0 0}$ habitantes localizado en la provincia de Toledo (España), eminentemente residencial, situado estratégicamente en un entorno de municipios industriales y entre dos grandes ciudades que ejercen un potente efecto atractor de los movimientos generados en Villaluenga: Madrid (65 km) y Toledo (25 km).

\section{Discusión y desarrollo}

\section{Planteamiento del problema}

De los cuatro objetivos planteados en el apartado anterior, los dos primeros tienen que ver con el tipo de método y la forma de integrarlo dentro del proceso urbanístico.
This importance of road traffic is justified for many reasons among which may be included those related to urban design. Nowadays dynamics of urban planning is oriented toward single-family building types, intensive in terms of the amount of land needed and, therefore, mostly dependent on private road traffic transport (Correa, 2010).

In this context, it would be useful to have a mechanism to know and to compensate GHG emissions due to road traffic in cities: The requirements for such mechanism and the objectives of this study are:

1. Propose a method to help identify the responsible for greenhouse gases emission so that the cost resulting from any compensation can be imputed to such part.

2. The method should be integrated at an early stage in which compensation of emissions is possible, at least theoretically, through urban design instruments.

3. The method should provide a useful mechanism in order to quantify the source of GHGs generation due to traffic.

4. Finally, it must provide comparable results with the actual data generation that can be measure once implemented urban developments.

In this paper we will propose a methodology for determining GHG emissions based on techniques of spatial distribution of traffic and provide solutions to the above limitations. To expose practical application of the proposed model it will be analyzed Villaluenga de La Sagra sample, a town of 3,000 inhabitants located in Toledo province (Spain), largely residential, strategically located in an environment of industrial cities and between two large cities that exert a strong effect attractor of movements generated in Villaluenga: Madrid $(65 \mathrm{~km})$ and Toledo $(25 \mathrm{~km})$.

\section{Discusion and development}

\section{Problem Statement}

Of the four goals outlined in the previous section, the first two have to do with the type of method and how to integrate it into the urban planning process. 
La vinculación del modelo el proceso de diseño urbanístico permite su equiparación con el cálculo ex ante (Intergovernmental Panel on Climate Change, 2003), del que resultará una cifra estimativa de las emisiones de GEI.

El cálculo real de las emisiones deberá realizarse con carácter ex post (Intergovernmental Panel on Climate Change, 2003) basándose en técnicas de aforo y medición real del tráfico que permitan la identificación del origen y destino de los movimientos y contrastar la veracidad de las hipótesis de cálculo que se consideren en el modelo.

Ahora bien, la estimación ex ante permite la inclusión de mecanismos de corrección en el propio proceso urbanístico al aportar información adicional que puede ser incluida también en los modelos de toma de decisiones respecto del diseño urbano (Transportation Research Board, National Academy of Science, 2000): definición de la trama viaria, tipología y localización de infraestructuras de conexión, demanda de sistemas de transporte público, incluso concentración o distribución espacial de las edificabilidades o densidad edificatoria, distribución de usos en el territorio...

El empleo de un mecanismo ex ante garantiza la propia regulación del proceso al permitir la posible inclusión de soluciones sencillas para la compensación de las emisiones dentro del propio diseño urbano mediante, por ejemplo, la reserva de superficies adicionales para zonas verdes (potenciales sumideros de los GEls) como medida compensatoria de las emisiones generadas.

Obviamente, la compensación de las emisiones también podría realizarse vía adquisición de algunos de los tipos de derechos de emisión disponibles en el mercado. A los efectos prácticos, la diferencia entre la adquisición de los derechos de emisión o la inclusión de superficies adicionales para zonas verdes, deberá compararse en términos monetarios en función del coste de adquisición de esos terrenos adicionales para incorporarlos como carga a los desarrollos urbanos cuya compensación de GEls se desea realizar. No obstante, la incorporación de superficies adicionales como zonas verdes genera ventajas adicionales (algunas de las cuales constituyen externalidades del proceso urbanizador) y resulta más sencillo de instrumentar al concebirse como una carga al proceso urbanizador y no como una imposición municipal (o concepto equivalente para la adquisición de derechos en cualquiera de sus formas).
Linking the model, the urban design process allows its alignment to the ex ante calculation (Intergovernmental Panel on Climate Change, 2003), resulting estimated GHG emissions.

Actual calculation of emissions must be made as ex post (Intergovernmental Panel on Climate Change, 2003) based on technical capacity and actual traffic measurements that allow the identification of the origin and destination of movements and contrast the veracity of the hypothesis calculation considered in the model.

The ex ante estimation allows the inclusion of correction mechanisms in the urban planning process by providing additional information that may also be included in the models of decision-making about urban design (Transportation Research Board, National Academy of Science, 2000): plot definition of roads, type and location of connection infrastructure, demand for public transportation systems, including concentration or spatial distribution of density or buildable areas, distribution of uses of land ...

The use of a mechanism ex ante guaranteeing regulation of the process by allowing possible inclusion of simple solutions to compensate emissions within urban design, for example, reservation of additional zones for green areas (potential sinks of GHGs) as a compensatory measure of the generated emissions.

Obviously, compensation of emissions could also be made purchasing certain types of emission allowances available on the market. For practical purposes, the difference between the acquisition of emision rights or the inclusion of additional areas for parks, should be compared in monetary terms based on the cost of acquiring such additional land to be incorporated as a filler to urban developments which compensation GHG is desired. However, the inclusion of additional areas as parks creates additional benefits (some of which are externalities of housing development) and it is easier to implement if seen as a burden to urbanization process and not as municipal taxation (or equivalent concept for rights adquisiton in any form). 
Quedando así justificada la conveniencia de considerar un método ex ante que se incorpore en el proceso de planeamiento urbano, el tercer objetivo perseguidoe aludía al propio método y a sus resultados esperados en términos de la posterior estimación de emisiones de GEls. Debe recurrirse a un método que permita cuantificar la generación del tráfico rodado responsable de las emisiones de gases referidas.

Este método debe también caracterizar el tráfico generado distribuyéndolo entre cada recorrido existente dentro del municipio que se estudia. No debe obviarse que en muchos de los casos, los movimientos generados en los municipios tienen un ámbito de influencia muy superior al local, razón por la que el método debe partir de la hipótesis de que el tráfico generado es atraído en función de variables de orden supramunicipal.

Así, para la definición de un método capaz de satisfacer las necesidades anteriores se recurre a los modelos de distribución espacial de tráfico. Estos modelos constituyen una herramienta para el estudio de la generación y distribución del tráfico, especialmente rodado, en las ciudades.

Dentro de los modelos de distribución espacial, los gravitacionales son técnicas matemáticas sencillas mediante las que puede estimarse desde un punto de vista teórico la forma en la que se distribuye la cantidad de tráfico rodado que se genera en una cierta actividad.

El último de los pasos hace referencia a la transformación de los resultados de la simulación de los métodos gravitacionales en términos de cantidad de GEls, proceso para el que se recurre a las tasas de generación previstas para cada tipo de transporte.

\section{Metodología}

Centrando por tanto, el estudio en el método gravitacional, este modelo asume que el flujo de movimientos entre dos zonas $i$, $j$, denominado $N_{i j}$, es directamente proporcional a la generación tráfico en la zona origen i y a la atracción que ejerce la zona destino j, e inversamente proporcional al coste del desplazamiento entre las dos zonas (Willumsen, 1985):
Having well justified the advisability of an ex ante approach incorporated to the urban planning process, the third objective alluded to the method and its expected results in terms of the subsequent estimation of GHG emissions. A method must be used in order to quantify the traffic generation responsible for the referred gas emissions.

This method should also characterize the traffic generated by distributing it on each existing route within the municipality that is being studied. It should not be forgotten that in many cases movements generated in municipalities have a much larger level of influence than the local one, and that is why the method should be based on the assumption that traffic generated is drawn according to supra municipal variables.

Thus, for the definition of a method capable of meeting the above needs spatial distribution of traffic models are used. These models are a tool for studying generation and distribution of traffic, especially the road one, in the cities.

Within spatial distribution models, mathematical simple techniques allow to estimate from a theoretical point of view the way in which is distributed the amount of road traffic generated by a certain activity.

The last step is the transformation of simulation results of gravitational methods in terms of quantity of GHGs, a process which uses the generation rates considered for each type of transport.

\section{Methodology}

Focusing the study on gravitational method, this model assumes that the flow of movement between two zones $\mathbf{i}$, j, called $N_{i j}$, is directly proportional to traffic generation in the area of origin $i$ and to the attraction of the destination zone $\mathbf{j}$, and inversely with the cost of travel between the two areas (Willumsen, 1985):

$$
N_{i j}=g_{i} a_{j} F\left(c_{i j}\right)
$$

Donde $g_{i}$ representa la generación en la zona i, $a_{j}$ representa la atracción de la zona j y $F\left(c_{i j}\right)$ es la denominada función de fricción que introduce en el modelo la variable relacionada con el coste.
Where $g_{i}$ represents the generation in area $\mathbf{i}, a_{j}$ represents the attraction of the area $\mathbf{j}$, and $F\left(c_{i j}\right)$ is called friction function, which introduces in the model the variable related to cost. 
La máxima simplificación del modelo anterior permitiría su expresión de la forma siguiente:
Maximum simplification of the previous model would be as follows:

$$
N_{i j}=g_{i} p_{j} \frac{1}{d_{j}^{a}}
$$

En la función anterior ya se concretan las variables definidas genéricamente en un primer momento:

- Atracción del destino, puesto que $p_{j}$ representa la población en cada uno de los posibles puntos destino, acotándose así el concepto $a_{j}$.

- La generación de tráfico $g_{i}$ depende de las actividades que la producen y deberán ser específicas para cada una de ellas.

- Función de fricción $F\left(c_{i j}\right)=\frac{1}{d_{j}^{a}}$ en la que $d_{j}^{a}$ representa la distancia desde el origen al destino j y que adopta una forma potencial para ponderar el factor distancia. A la potencia $a$ se le denomina factor de fricción.

A los efectos prácticos y por cuestiones de operatividad el modelo suele expresarse agrupando las variables que dependen del destino $r_{j}$ independizándolas de las que dependen del origen $g_{i}$ :
In the above function variables are specified generically defined at a first moment as:

- Destination's appeal, since $p_{j}$ represents population in each of the possible target points, limiting thus the concept $a_{j}$.

- Traffic generation $g_{i}$ depends on the activities that produce and must be specific for each of them.

- Role of friction $F\left(c_{i j}\right)=\frac{1}{d_{j}^{a}}$ in which $d_{j}^{a}$ represents the distance from origin to destination $j$, which takes a potential way in order to weight the distance factor. Potential $a$ is called friction factor.

For practical purposes and operational issues the model usually is expressed by grouping variables that depend on destination $r_{j}$ making them independent from their dependent source $g_{i}$ :

$$
\begin{aligned}
& N_{i j}=g_{i} p_{j} \frac{1}{d_{j}^{a}}=g_{i} r_{j} \\
& r_{j}=p_{j}{\frac{1}{d_{j}^{a}}}
\end{aligned}
$$

Donde $r_{j}$ suele denominarse coeficiente de reparto.

La versión simplificada del modelo anterior cuenta con la ventaja de su sencillez y la facilidad para obtener la información relativa a cada una de las variables que intervienen: número de habitantes de las poblaciones en el ámbito de influencia y distancias a esas poblaciones.

Ahora bien, esta supuesta ventaja se traduce en una evidente pérdida de información que puede hacer discutible la certeza de los resultados obtenidos. La primera de las variables simplificadas cuyo contenido puede ampliarse es el denominado coeficiente de reparto. Este factor incluye el conjunto de variables de las que dependerían los movimientos entre el punto generador y las distintas zonas de atracción (Ortúzar y Román, 2003).
Where $r_{j}$ often called partition coefficient.

The simplified version of the previous model has the advantage of simplicity, becoming easy to obtaining information regarding each variables involved: number of inhabitants of the different towns in the area of influence and distances to these populations.

However, this supposed advantage is translated into an evident loss of information that can make questionable the accuracy of results.

The first simplified variable which content may be extended is called partition coefficient. This factor includes the set of variables of which may depend the movements between the generating point and the different attraction areas (Ortúzar y Román, 2003). 
La máxima simplificación planteada anteriormente considera que los movimientos que se generan en el punto en estudio y que se dirigen hacia el resto de puntos posibles de atracción son directamente proporcionales a la población del destino e inversamente proporcionales a la distancia entre ambos puntos. En el presente trabajo se asume que la existencia de movimientos entre dos puntos puede venir motivada por alguna de las tres razones siguientes:

- Motivos personales: se escoge la variable población como medida de la probabilidad de que los habitantes de la ciudad origen tengan relaciones familiares o de afinidad con la población destino.

- Motivos laborales: la probabilidad de que un habitante de la ciudad destino deba trasladarse hacia otra población para trabajar dependerá de la cantidad de empresas que estén domiciliadas en la población destino. Por esta razón se escoge el número de empresas que según las fuentes estadísticas estén radicadas en cada de las posibles poblaciones destino.

- Motivos comerciales o de ocio: Se agrupan dentro de una misma categoría estos tipos de movimiento por cuanto en la actualidad muchas de las zonas rurales dependen para sus compras y el ocio de las grandes superficies en las que coexisten súper e hipermercados con establecimientos de ocio. Para medir esta justificación de los movimientos se recurre al número de establecimientos comerciales radicados en cada uno de los posibles municipios destino.

Una vez definidas las variables que intervienen, debe discutirse la forma en la que se combinan para obtener los resultados deseados. Para definir este aspecto se supone que los movimientos basados en motivos laborales suponen el $\mathbf{5 0} \%$ del total mientras que los personales y de ocio representan, respectivamente, el $25 \%$.

La metodología concreta de tratamiento supone la obtención de una suma ponderada de tantos por uno de cada una de las variables:
Maximum simplification considers that the movements that are generated at the point being studied and directed toward other possible points of attraction are directly proportional to population of destination and inversely proportional to the distance between both points. In this paper the existence of movements between two points is assume as arising from one of the following three reasons:

- Personal reasons: the population variable is chosen as a measure of probability that the origin city dwellers have family relationships or affinity with population of destination.

- For work: the probability that a destination city dweller should move to another town to work will depend on the number of companies established at the destination town. For this reason we choose the number of companies that statistical sources consider established in each of the potential destination places.

- Commercial or recreational reasons: They are grouped into a category such movements because today many rural communities depend for their shopping and entertainment from superstores in supermarkets and hypermarkets that coexist with leisure facilities. To measure this justification of movements the number of commercial establishments located in each of the municipalities of destination are used.

Having defined the variables involved, it must be discussed how they combine in order to get the desired results. To define this aspect, it is assumed that labor based movements account $50 \%$ of the total while the personal and leisure ones represent respectively $25 \%$.

Particular treatment method involves obtaining a weighted sum of many one of each of the variables:

$$
r_{j}=\left[0.25\left(\frac{p_{j}}{\sum_{j=1}^{j=m} p_{j}}\right)+0.50\left(\frac{e_{j}}{\sum_{j=1}^{j=m} e_{j}}\right)+0.25\left(\frac{c_{j}}{\sum_{j=1}^{j=m} c_{j}}\right)\right] \frac{1}{d_{j}^{a}}
$$

Donde $p_{j}$ representa la población de cada uno de las posibles poblaciones destino, $e_{j}$ hace referencia al total de empresas de cada uno de los posibles puntos destino y $c_{j}$ alude al total de establecimientos comerciales.
Where $p_{j}$ representa population of each one of possible destination populations, $e_{j}$ refers to total companies of each one of possible destination points and $c_{j}$ aludes to total commercial places. 
Con respecto al contrapeso que minore estas razones, se mantiene la dependencia de la distancia entre ambos puntos como principal variable que opera en contra de los movimientos anteriores.

La expresión anterior para el coeficiente de reparto $r_{j}$ permite conocer la capacidad de atracción de los municipios del entorno de influencia, con lo que para conocer el flujo $\left(\mathrm{N}_{\mathrm{ij}}\right)$ queda pendiente conocer la cantidad de movimientos generados en la zona origen $\mathbf{i}\left(g_{i}\right)$. Para definir esta generación se recurre a cada uno de los usos urbanísticos del municipio origen aplicando coeficientes de generación. En condiciones normales estas tasas de generación se basan en estudios empíricos, para el presente trabajo se han empleado tasas de generación frecuentemente empleadas en los estudios de tráfico de la Comunidad de Madrid:

- Uso residencial: 0,46 viajes de vehículo motorizado por persona residente (suponiendo una ocupación media de 3 personas por vivienda).

- Usos productivos:

o Comercial: 0,04 viajes $/ \mathrm{m}^{2}$ construidos $(15 \%$ vehículos pesados);

o Industrial: 0,014 viajes $/ \mathrm{m}^{2}$ construidos $(80 \%$ vehículos pesados);

o Equipamiento: 0,016 viajes/m² $/ \mathrm{m}^{2}$ de suelo.

En las zonas ya habitadas se considera una tasa de generación de movimientos de 2,4 trayectos por habitante y día (valor típico de poblaciones del entorno), el $35 \%$ de los cuales se realizan con vehículos pesados.

Una vez conocida la generación, para la correcta cuantificación de los GEls debe considerarse el reparto modal entre las alternativas de transporte. En el presente trabajo se considera el reparto de los movimientos únicamente entre las alternativas del vehículo privado y el autobús público, puesto que no existe estación de ferrocarril próxima y, en este caso, para acceder a la estación debe salirse del término mediante vehículo privado.

Una vez conocida la cantidad de movimientos generados y los posibles destinos de los mismos debe repartirse entre la red viaria planeada. Para ello se supone que cada zona de uso homogéneo prevista por el planeamiento urbanístico genera todo su tráfico en un centroide que constituye el punto de partida para la definición de cada una de las rutas que deben seguirse hasta acceder a los puntos destino.
With respect to the counterweight to slow these reasons, it is maintain the dependence of distance between two points as the main variable that works against previous movements.

The above expression for the distribution coefficient $r_{j}$ provides information about attractiveness capacity of municipalities and surrounding areas of influence, so that to know flow $\left(N_{i j}\right)$ remains to know the number of movements generated in the origin zone $\mathbf{i}\left(g_{j}\right)$. To define this generation each of origin urban municipality uses are taken into consideration, generating source coefficients. Under normal conditions these generation rates are based on empirical studies; for this work have been used frequently generation rates used in traffic studies of Madrid Community:

- Residential use: 0,46 motor vehicle trips per resident (assuming an average occupancy of 3 persons per household).

- Productive uses:

o Commercial: 0,04 trips/builded $\mathrm{m}^{2}$ (15\% heavy vehicles);

o Industrial: 0,014 trips/builded $\mathrm{m}^{2}(\mathbf{8 0} \%$ heavy vehicles);

o Equipment: 0,016 trips/land $\mathrm{m}^{2}$.

In areas already inhabited it is considered a movements generation rate of $\mathbf{2 . 4}$ trips per capita per day (typical value of the surrounding villages), $35 \%$ of which are made with heavy vehicles.

Once the generation is known for the correct quantification of GHGs should be considered modal distribution between transport alternatives. In this paper the distribution of movements is considered only between the alternatives of private vehicles and public buses, as there is no railway station nearby and, in this case, to access the train station one should get out the term by private vehicle.

Once known the number of movements generated and possible destinations of them it must be divided among the planned road network. This assumes that each homogeneous area of use provided by urban planning generates all its traffic from a centroid which is the starting point for defining each of the routes to be followed in order to access the destination points. 
En condiciones habituales, este proceso se realiza identificando las vías supramunicipales a través de las que se llega a cada destino y repartiendo en los viales interiores hasta acceder a esas vías en función de la mínima distancia a recorrer hasta llegar a ellas. En el presente trabajo se pretende ampliar la cantidad de información que se incorpora en el modelo y el proceso de reparto del tráfico generado. Por ello se aborda esta cuestión en las fases siguientes:

- Identificación del total de vías que permiten llegar hasta cada punto de destino y reparto en función de los porcentajes siguientes: autovía, $70 \%$; carretera nacional, $20 \%$; peaje, $10 \%$; otros, $10 \%$ (en caso de que para llegar a alguna localidad no se disponga de todas las alternativas, el tráfico se repartirá entre las existentes manteniendo los repartos proporcionales anteriores).

- Para la determinación de las rutas interiores seguidas hasta cada una de las vías anteriores, se complementa el criterio de mínima distancia con el de menor número de intersecciones, de forma que se asume que parte de los movimientos escogen el recorrido con la mínima distancia mientras que el resto prefieren optan por un recorrido en el que se espera una menor congestión aun a costa de una mayor longitud.

Existe una variable adicional a considerar en el modelo y que está representada por el tráfico interior. En municipios de la naturaleza del considerado los movimientos interiores cuentan con mucha menor relevancia que los exteriores, razón por la que los movimientos exteriores pueden considerarse un $5 \%$ del tráfico calculado para cada uno de los tramos de la red viaria.

\section{Resultados}

El término municipal de Villaluenga de La Sagra se encuentra en España, al norte de la provincia de Toledo, en la comarca de La Sagra, a una distancia de $21 \mathrm{Km}$ a la capital de la provincia y a $65 \mathrm{~km}$ de Madrid, la capital del país.

Cuenta con un núcleo urbano central de carácter residencial y 2.776 habitantes y una urbanización aislada al sur (denominada La Jerecita) que cuenta con 693 habitantes censados.
In normal conditions, this process is done by identifying supra-municipal roads through which one gets to each destination and distributing the rest in the interior roads until accessing those pathways according to the minimum travel distance to reach them.

In the present work it is extended the amount of information incorporated into the model and the process of distribution of traffic generated. So this issue is addressed in the following phases:

- Identification of all pathways that enable to reach each destination and delivery point based on the following percentages: highway, $70 \%$; national highway, $20 \%$; toll, $10 \%$; others $10 \%$ (in case of not having available all the alternatives upon reaching a locality, traffic is divided between the existing ones maintaining proportional distributions above mentioned).

- For the determination of domestic routes followed until each one of the above ways, the minimum distance criteria is complemented with the least number of intersections, so it is assumed that part of movements choose the route with the minimum distance while the rest prefer to choose a tour that is expected to have less congestion even if it has a greater length.

There is an additional variable to consider in the model and is represented by domestic traffic. In municipalities as the one considered here the interior movements have much less importance than the exterior ones, and that is why the outer movements can be considered of an estimated of $5 \%$ of the traffic for each of the sections of the road network.

\section{Results}

The municipality of La Sagra Villaluenga is in Spain, north of the province of Toledo, in the region of La Sagra, a distance of $21 \mathrm{~km}$ to the province capital and $65 \mathrm{~km}$ from Madrid, the country capital .

It has a central urban residential core and $\mathbf{2 . 7 7 6}$ inhabitants and urbanization isolated to the south (called La Jerecita) which has 693 registered inhabitants. 


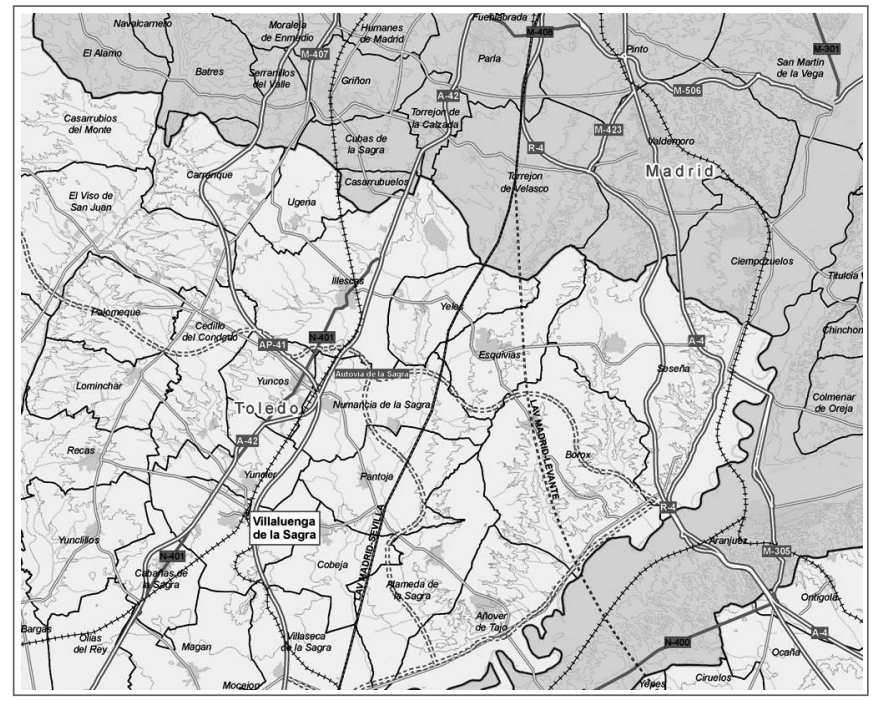

Figura 1. Localización Villaluenga de la Sagra

Figure1. Localization of Villaluenga de la Sagra

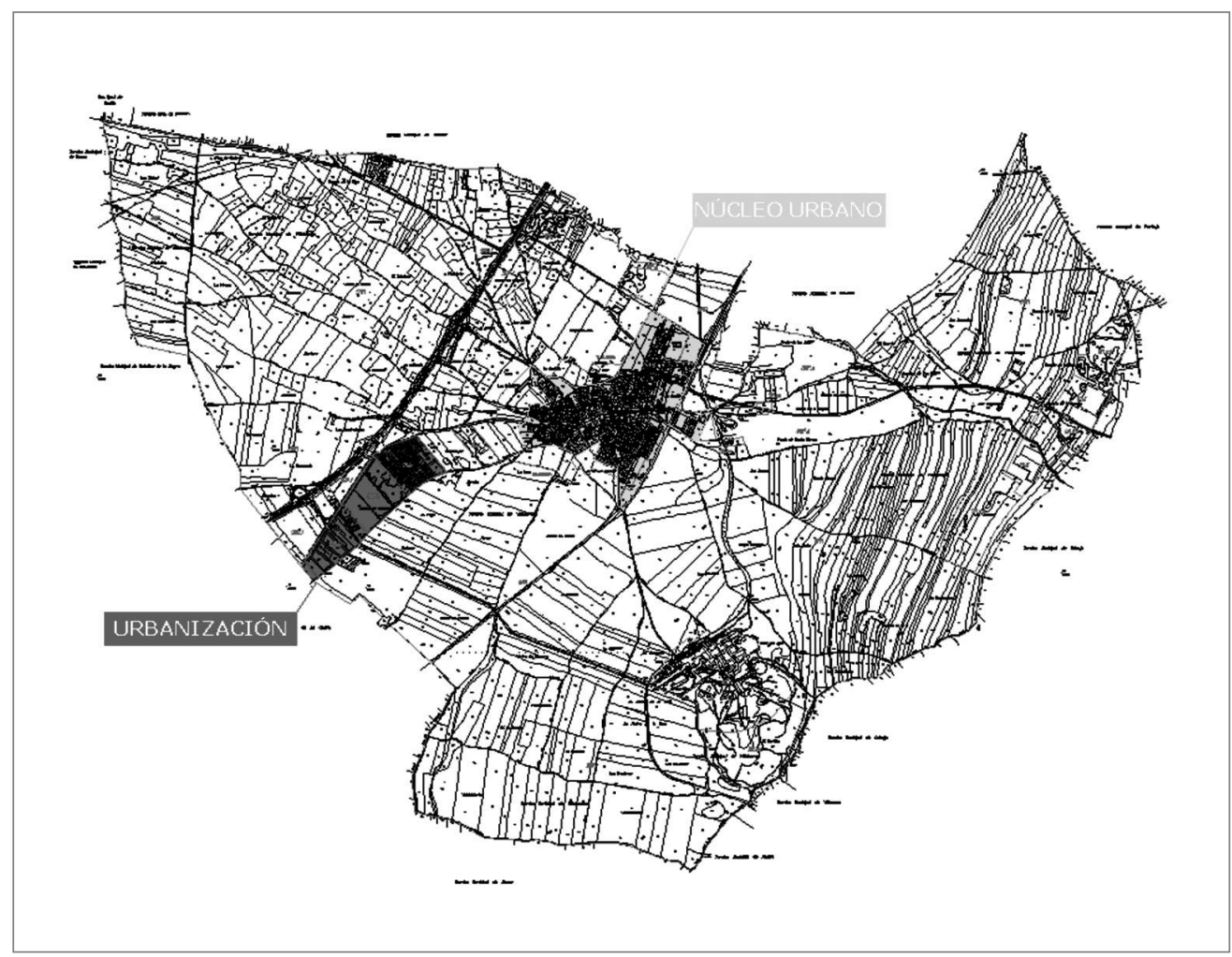

Figura 2. Núcleos de población existentes en Villaluenga de la Sagra

Figure 2. Existing core population of Villaluenga de la Sagra

El proceso supone la cuantificación de los movimientos generados en primer lugar en los núcleos urbanos ya existentes aplicando las tasas expuestas en la metodología anterior:
The process involves quantification of movements generated in the first place in existing urban areas by applying the rates set forth in the above methodology: 
Tabla 1. Generación de tráfico en los núcleos urbanos actuales

Table 1. Traffic generation in the current urban core

\begin{tabular}{||l|c|c|c||}
\hline \multirow{2}{*}{ ZONA/ZONE } & \multirow{2}{*}{ MOVIMIENTOS DIARIOS/DAILY MOVEMENTS } \\
\cline { 3 - 4 } & HABITANTES/INHABITANTS & LIGEROS/LIGHT & PESADOS/HEAVY \\
\cline { 3 - 4 } & & $4.330,30$ & $2.331,70$ \\
\hline NÚCLEO URBANO/URBAN NUCLEOUS & $2.776,00$ & $\mathbf{1 . 0 8 0 , 9 5}$ & 582,05 \\
\hline
\end{tabular}

También debe estimarse la cantidad de tráfico que se generan en las zonas de crecimiento previstas por el planeamiento. La imagen siguiente muestra el plano de clasificación del territorio futuro previsto en el término municipal:
One should also estimate the amount of traffic generated in expected planned growth areas. The following image shows the plan of classification of future land considered by the municipality:

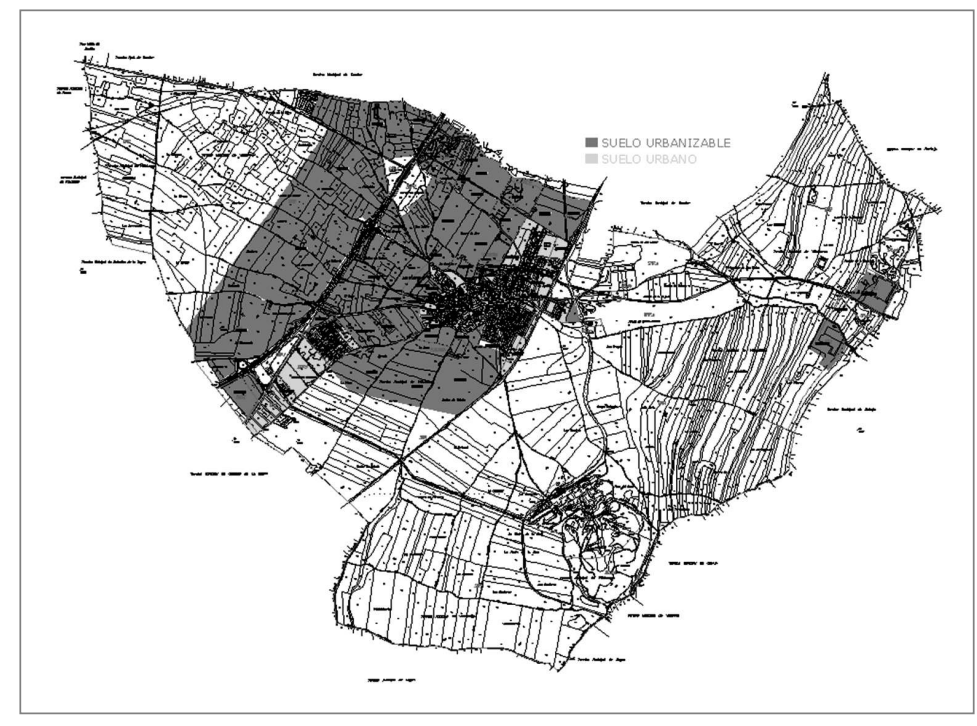

Figura 3. Crecimientos previstos por el planeamiento urbanístico Figura 3. Growth expected for urban planning

La cantidad de movimientos que se prevé generarán los crecimientos propuestos se obtienen a partir de la aplicación de tasas de generación de tráfico ya expuestas sobre los parámetros urbanísticos de cada uno de los sectores de suelo urbanizable (ver Tabla A.1 del Anexo 1).

Una vez conocido la cantidad de desplazamientos que se generarán, el siguiente paso consiste en identificar aquellos puntos que pueden ser destino de tales movimientos. Para ello, se seleccionan las ciudades y municipios más relevantes del entorno y que se encuentran a una distancia tal que permite su influencia. Se calculan los coeficientes de reparto a partir de los datos de la población y número de empresas comerciales y total (ver Tabla A.2 del Anexo 1).
The number of movements that will generate the growth expected are obtaines from proposed application rate traffic generation and urban parameters displayed on each of the sectors of land for development (see Table A.1 Anex 1).

Once you know the number of trips to be generated, the next step is to identify those points that can be target of such movements. To do this, select the most important cities and towns of the environment and which are located at such a distance that it allows the influence. Calculate the distribution of coefficients from the data of population and number of commercial companies and total (see Table A.2 Anex 1). 
El factor de fricción empleado ha sido 1,5 (valor habitual para recorridos de distancia media).

Una vez conocidos los datos anteriores debe procederse al reparto de los flujos entre cada uno de los viales posibles. La primera de las tareas a realizar consiste en identificar los puntos de conexión con las distintas vías supramunicipales que permiten llegar hasta los puntos de destino referidos. Son los siguientes:

- Autovía A-42 Madrid-Toledo que permite las conexiones del núcleo urbano con las poblaciones del norte y del sur.

- Carretera Nacional N-401, antigua carretera MadridToledo, que permite la conexión únicamente en dirección sur.

- Carretera CM-9050, que conecta con los municipios del oeste desde el norte de Villaluenga de la Sagra.

- Carretera TO-4511 conecta con los municipios ubicados al este del municipio.

- Autopista de peaje AP-41 conecta con Madrid o Toledo únicamente.

Estas infraestructuras viarias se observan en la imagen siguiente:
The friction factor used was 1.5 (typical value for medium-distance routes).

Once you know prior data you should performe distribution of flows between each of the possible roads. The first of the tasks is to identify the connection points with the different supra municipal ways that enable to reach the destinations places mentioned. They are:

- Highway A-42 Madrid-Toledo that allows connections to the urban core with north and south populations.

- National Highway N-401, ancient highway MadridToledo, that allows connections only toward south.

- Highway CM-9050, connects the towns of the West from North Villaluenga de la Sagra.

- Highway TO-4511 connects with towns located at the East.

- Toll Highway AP-41 connects only with Madrid or Toledo.

These road infrastructure are seen in the picture below:

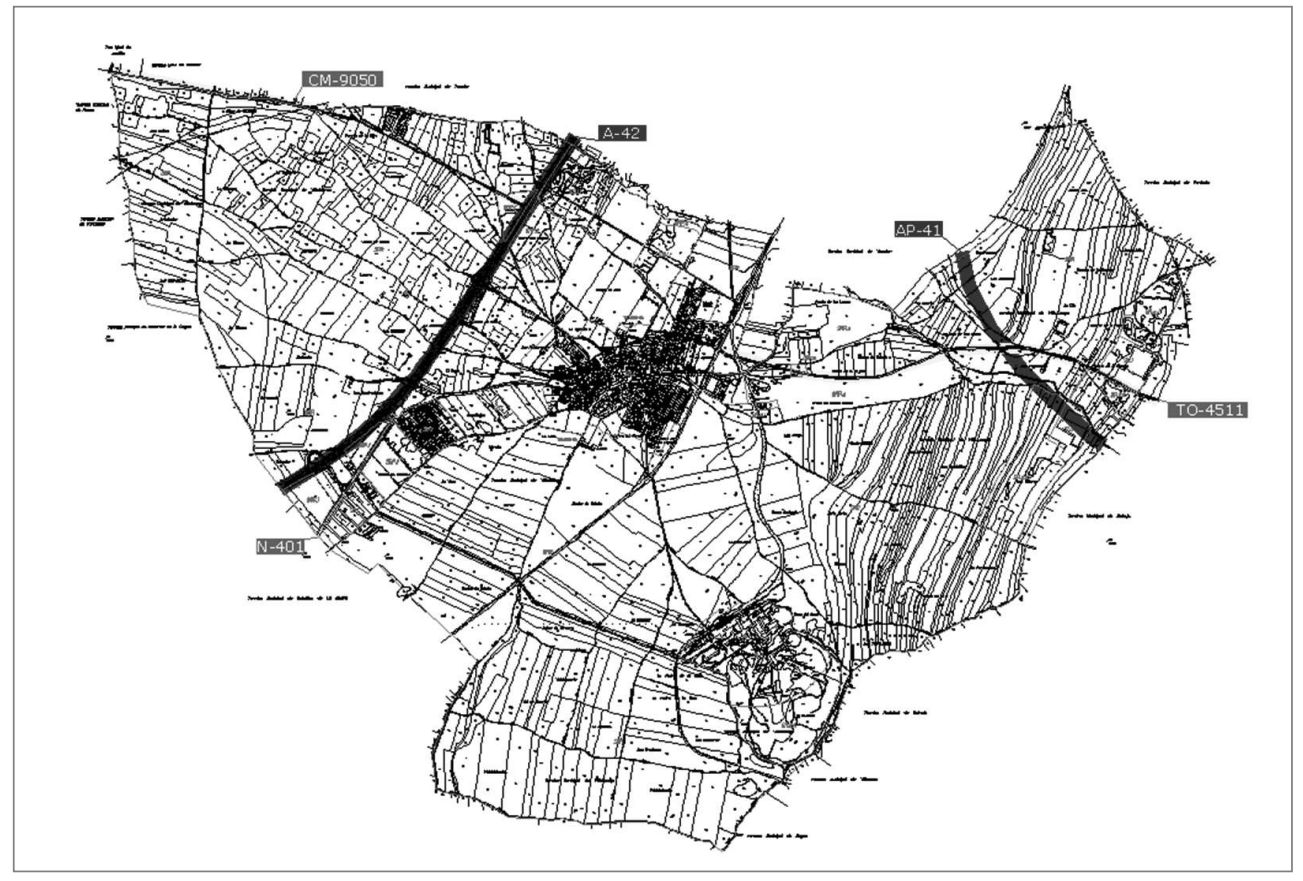

Figura 4. Infraestructuras presentes en Villaluenga de la Sagra

Figure 4. Present infrastructures in Villaluenga de la Sagra

Como complemento a las infraestructuras anteriores, el planeamiento prevé una nueva red viaria interior que ordene el tráfico generado. Es la siguiente:
In addition to the above infrastructure, the plan foresees a new internal road network to order the generated traffic. It is: 


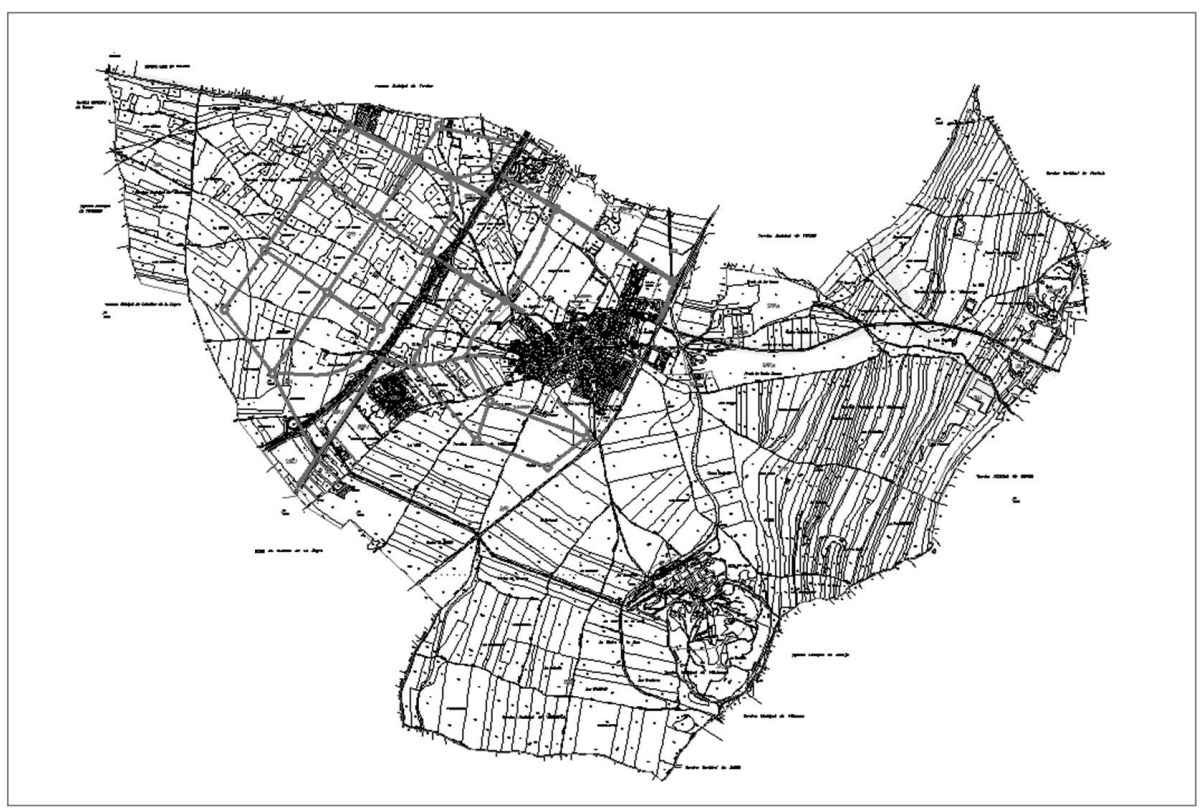

Figura 5. Red viaria interior y conexiones supramunicipales

Figure 5. Internal road network and connections among municipalities

Una vez identificadas las vías supramunicipales, sus posibles conexiones, el paso siguiente consiste en imputar a cada una de las infraestructuras la parte de los movimientos que desde cada sector de origen se dirigen hacia cada uno de los puntos destino en función de los porcentajes de uso esperados para cada tipo de infraestructura referidos en el apartado metodológico (ver Tabla A.3 del Anexo 1).

Por ejemplo, para llegar a Madrid desde Villaluenga de La Sagra, el $88 \%$ de los movimientos se realizarán a través de la $\mathrm{A}-42$ y el $12 \%$ restante se realiza a través de la AP-41, mientras que en el caso de Toledo, el $89 \%$ se realiza a través de la $\mathrm{A}-42$, el $5,5 \%$ por la $\mathrm{N}$ 401 y el 5,5\% restante mediante la AP-41.

A continuación debe distribuirse el coeficiente de reparto $\left(r_{j}\right)$ de cada uno de los posibles destinos en función de los porcentajes anteriores (la relación total de estos porcentajes se incluye en la Tabla A.3 del Anexo 1). El resultado de esta distribución se incluye en la Tabla A.4 del Anexo 1.

Por ejemplo el coeficiente de reparto de Madrid es el $37.52 \%$ (cifra que representa la parte de los movimientos que se generan en un sector y que se dirigen a Madrid) que se reparte entre la A-42 (33.01\% que representa el $88 \%$ del $37.52 \%$ y representa la parte de los generados que irán a Madrid a través de la A-42) y la AP-41 $(4.01 \%$ que resulta ser el $12 \%$ del $37.52 \%$ que alude a la parte de los movimientos generados que irán a Madrid y que lo harán a través de la AP-41).
Once identified supra pathways, their possible connections, the next step is to allocate to each infrastructure the movements that from every sector of origin are directed toward each destination points, based on the percentages of use expected for each type of infrastructure referred to in methodology chapter (see Table A.3 in Annex 1).

For example, to reach Madrid from Villaluenga de La Sagra, $88 \%$ of movements will be made through A-42 and the remaining $12 \%$ done through AP-41, whereas in the case of Toledo, $89 \%$ will be done through A-42, 5.5\% through $\mathrm{N}-401$ and the remaining $5.5 \%$ by AP-41.

Then it must be distributed the distribution coefficient $\left(r_{j}\right)$ of each possible destinations based on the above percentages (the total ratio of these percentages are included in Table A.3 of Annex 1). The result of this distribution is included in Table A.4 in Annex 1.

For example, the distribution coefficient of Madrid is $\mathbf{3 7 . 5 2} \%$ (representing movements generated in one sector and aimed toward Madrid) is shared between A-42 (33.01\% represents $88 \%$ of $37.52 \%$ and represents the portion of what will go to Madrid generated through A-42) and AP-41 $\mathbf{( 4 . 0 1 \%}$ which happens to be $12 \%$ of $37.52 \%$ refered to the generated movements that will go to Madrid through AP-41). 
En el caso de Toledo el coeficiente de reparto resulta ser del $6.11 \%$ que se reparte entre la A-42 (el $89 \%$ del $6.11 \%$ que supone un $5.44 \%$ ), la $\mathrm{N}-\mathbf{4 0 1}$ (el $5.5 \%$ del $6.11 \%$ que supone un $0.34 \%$ ) y la AP-41 (el $5.5 \%$ del $6.11 \%$ que también es un $0.34 \%$ ).

Una vez conocidos los coeficientes de reparto específicos de cada uno de los posibles accesos hacia cada uno de los posibles puntos destino el paso siguiente consiste en determinar los recorridos interiores desde cada una de las zonas de generación hasta ganar cada una de los posibles accesos.

Para realizar este paso se supone que la totalidad del tráfico generado por cada una de las zonas se concentra en su centroide. Por ejemplo desde el sector $\mathrm{SO} 6$ industrial cuyo tráfico se genera en el centroide 1, debe recorrer los tramos 5 y 6 para acceder a la autovía A-42, o los tramos 1, 2, 5 y 7 (o 1, 2, 3 y 4) para dirigirse hacia los municipios del oeste a través de la carretera CM-9050.
In the case of Toledo the distribution coefficient turns out to be $6.11 \%$ which is distributed among A-42 (89\% of $6.11 \%$, representing a $5.44 \%), \mathrm{N}-401(5,5 \%$ of $6.11 \%$ representing a $0.34 \%)$ and AP-41 $(5.5 \%$ of $6.11 \%$ which is also $0.34 \%$ ).

Once known the distribution coefficients specific for each of the possible access to each of the possible destination points, the next step is to determine the internal routes from each of the areas of generation until reaching each possible access.

To perform this step it is assumed that all the traffic generated by each of the zones is concentrated in its centroid. For example, from the industrial sector $\mathrm{SO}$ which traffic is generated at the centroid 1 , must go through the sections 5 and 6 in order to access highway A-42, or sections 1, 2, 5 and 7 (or 1, 2, 3 and 4) to go to the Western municipalities through the highway CM-9050.

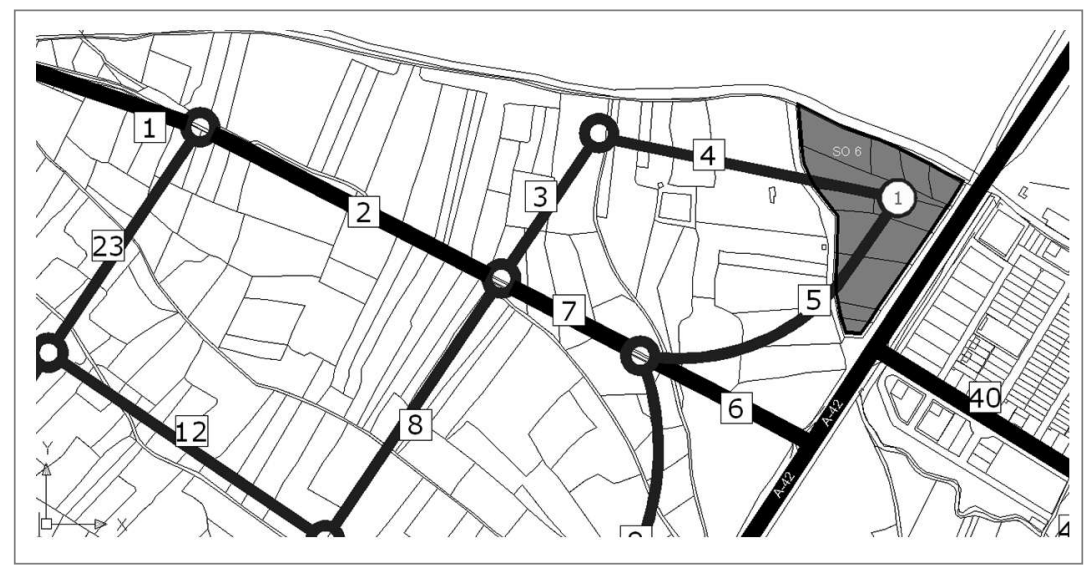

Figura 6. Ejemplo distribución de tráfico sector SO6 Figure 6. Example of traffic distribution sector so6

La cantidad de tráfico que el sector aporta a estos dos tramos será, de la cantidad de tráfico generado por éste (68.40 vehículos ligeros y 273.60 pesados) la parte proporcional que debe acceder a la A-42 para llegar a cada destino que se accede a través de esta autovía (el $0,06 \%$ de los movimientos - 68.40 y 273.60 -, que se dirigirán a Ajofrín, el $0.11 \%$ que se dirigirán hacia Argés y así sucesivamente con cada posible destino):

Este ejercicio debe realizarse para cada sector de crecimiento urbano de forma que en el último término se obtenga el total de movimientos en cada tramo de la red viaria. En el caso en estudio los resultados son los siguientes:
The amount of traffic contributed by the sector to these two sections will be the amount of traffic generated by it (68.40 273.60 heavy and light vehicles) the proportional part that must access A-42 to reach each destination with possible access through this road $(0.06 \%$ of movements - $\mathbf{6 8 . 4 0}$ and 273.60 - which will go toward Ajofrín, $0.11 \%$ to be directed towards Argés and so on for every possible destination):

This exercise should be performed for each urban growth area in order to obtain the total movement in each section of the road network. In the case study, the results are as follows: 
Tabla 2. Tráfico total de por tramos de la red viaria

Table 2. Total traffic network by number of road

\begin{tabular}{|c|c|c|c|c|c|c|c|c|c|c|}
\hline & 1 & 2 & 3 & 4 & 5 & 6 & 7 & 8 & 9 & 10 \\
\hline Turismos/Tourism & 79 & 10 & & & & 141 & 9 & 1 & & 7 \\
\hline \multirow[t]{2}{*}{ Pesados/Heavy vehicle } & 30 & 9 & & & & 534 & 3 & 6 & & \\
\hline & 11 & 12 & 13 & 14 & 15 & 16 & 17 & 18 & 19 & 20 \\
\hline Turismos/Tourism & 7 & 7 & 1 & & & & 1 & & 62 & 199 \\
\hline \multirow[t]{2}{*}{ Pesados/Heavy vehicle } & & & 6 & & & & 6 & & 21 & 582 \\
\hline & 21 & 22 & 23 & 24 & 25 & 26 & 27 & 28 & 29 & 30 \\
\hline Turismos/Tourism & 62 & 62 & 69 & 2.906 & 2.077 & 7.011 & 2.474 & 4.425 & 59 & 948 \\
\hline \multirow[t]{2}{*}{ Pesados/Heavy vehicle } & 21 & 21 & 21 & 618 & 93 & 2.553 & & 2.012 & & \\
\hline & 31 & 32 & 33 & 34 & 35 & 36 & 37 & 38 & 39 & 40 \\
\hline Turismos/Tourism & 259 & 4.366 & 9 & 388 & 563 & & 51 & 678 & 1.241 & 1.525 \\
\hline \multirow[t]{2}{*}{ Pesados/Heavy vehicle } & 93 & 2.012 & & & 85 & & & 316 & 401 & 287 \\
\hline & 41 & 42 & 43 & 44 & 45 & 46 & 47 & 48 & 49 & 50 \\
\hline Turismos/Tourism & 1.906 & 1.638 & 1.638 & 982 & 1.575 & 2.085 & 1.790 & 1.711 & 790 & 53 \\
\hline \multirow[t]{2}{*}{ Pesados/Heavy vehicle } & 671 & 671 & 676 & 418 & 541 & 97 & 584 & 316 & & \\
\hline & 51 & 52 & & & & & & & & \\
\hline Turismos/Tourism & 137 & 288 & & & & & & & & \\
\hline Pesados/Heavy vehicle & 561 & 973 & & & & & & & & \\
\hline
\end{tabular}

Una vez definidos los movimientos totales para cada uno de los tramos que componen las distintas rutas se procede a calcular las emisiones de GEls imputables al tráfico rodado (medidas como toneladas de $\mathrm{CO}_{2}$ equivalentes) del total de término municipal.

Para ello debe hacerse uso de factores de emisión que permitan transformar unidades de uso de los vehículos en toneladas de $\mathrm{CO}_{2}$ equivalentes. La fuente primitiva de estos factores de emisión se encuentra en las publicaciones del IPCC (IPCC, 2006) que incluyen factores de emisión para diferentes actividades económicas. En general estos factores de emisión se encuentran referenciados a características concretas de los combustibles empleados y que resultan de compleja aplicación práctica (poder calorífico del combustible empleado). Esto ha motivado el desarrollo de documentos que transforman estos factores indiciándolos a características más adecuadas a su empleo práctico (longitud recorrida por un vehículo). Entre estas iniciativas destaca el trabajo realizado por el Department for Environment, Food and Rural Affairs (DEFRA), del Reino Unido, cuyos factores han sido los empleados en el presente trabajo y se incluyen en la tabla siguiente (DEFRA, 2009)
Having defined the total movements for each one of the sections that form the different routes, it is calculated the GHG emissions attributable to road traffic (measured as tonnes of $\mathrm{CO}_{2}$ equivalent) of the total municipal area.

This should include use of emission factors that allow to translate units used by vehicles into tonnes of $\mathrm{CO}_{2}$ equivalent. The prime source of these emission factors are found in the publications of the IPCC (IPCC, 2006) including emission factors for different economic activities. In general, these emission factors are referenced to specific characteristics of fuels used and which result of complex practical implementation (calorific value of fuel used). This has motivated the development of documents which transform these factors indexed features best suitable to its practical use (length traveled by a vehicle). Among these initiatives is the work done by the Department for Environment, Food and Rural Affairs (DEFRA), United Kingdom, which factors have been used in this work and are included in the following table (DEFRA, 2009) 
Tabla 3. Coeficientes de generación de GEIS

Table 3. GHG generation coefficients

\begin{tabular}{||l|c|c|}
\hline \multicolumn{1}{|c|}{ Vehículo/Vehicle } & Factor & Unidades/Unities \\
\hline Turismo/Turism & 0,00020487 & $\mathrm{tCO}_{2} \mathrm{eq} / \mathrm{km}$ \\
\hline Autobús/Bus & 0,000367224 & $\mathrm{tCO}_{2} \mathrm{eq} / \mathrm{pasajero} \mathrm{km}$ \\
\hline Vehículo pesado/Heavy Vehicle & $\mathbf{0 , 0 0 0 9 3 4}$ & $\mathrm{tCO} \mathrm{C}_{2} \mathrm{eq} / \mathrm{t} \mathrm{km}$ \\
\hline
\end{tabular}

Se supone una ocupación media de los autobuses de 12 personas, una carga media de los vehículos pesados de 1.5 t y un $\mathbf{1 0} \%$ de los movimientos de turismo que son absorbidos mediante las líneas de autobús existentes que discurren en el interior del término una distancia de $4 \mathbf{~ k m}$.

Los resultados de este cálculo se observan en la Tabla siguiente:
It is assumed an average occupancy of buses of 12 people, an average load of heavy vehicles of $\mathbf{1 . 5}$ $t$ and $\mathbf{a} 10 \%$ of tourism movements that are absorbed by existing bus lines that run a distance inside the distance term of $4 \mathbf{~ k m}$.

The results of this calculation are seen in the following Table:

Tabla 4. Emisiones de GEIS por tramos de la red viaria

Table 4. GHG emissions by sections of road network

\begin{tabular}{|c|c|c|c|c|c|c|c|c|c|c|}
\hline & 1 & 2 & 3 & 4 & 5 & 6 & 7 & 8 & 9 & 10 \\
\hline Emisiones/Emissions $\left(\mathrm{tCO}_{2} \mathbf{e q}\right)$ & 0,1301 & 0,0056 & 0,0000 & 0,0000 & 0,0000 & 0,0836 & 0,0027 & 0,0012 & 0,0000 & 0,0013 \\
\hline TRAMO/SECTION & 11 & 12 & 13 & 14 & 15 & 16 & 17 & 18 & 19 & 20 \\
\hline Emisiones/Emissions $\left(\mathrm{tCO}_{2} \mathrm{eq}\right)$ & 0,0022 & 0,0025 & 0,0015 & 0,0000 & 0,0000 & 0,0000 & 0,0017 & 0,0000 & 0,0267 & 0,1243 \\
\hline TRAMO/SECTION & 21 & 22 & 23 & 24 & 25 & 26 & 27 & 28 & 29 & 30 \\
\hline Emisiones/Emissions $\left(\mathrm{tCO}_{2} \mathrm{eq}\right)$ & 0,0248 & 0,0290 & 0,0245 & 0,7870 & 0,5036 & 1,7463 & 1,0495 & 1,9273 & 0,0166 & 0,2434 \\
\hline TRAMO/SECTION & 31 & 32 & 33 & 34 & 35 & 36 & 37 & 38 & 39 & 40 \\
\hline Emisiones/Emissions $\left(\mathrm{tCO}_{2} \mathbf{e q}\right)$ & 0,0866 & 1,3618 & 0,0041 & 0,1129 & 0,2062 & 0,0000 & 0,0121 & 0,1619 & 0,5283 & 0,5610 \\
\hline TRAMO/SECTION & 41 & 42 & 43 & 44 & 45 & 46 & 47 & 48 & 49 & 50 \\
\hline Emisiones/Emissions $\left(\mathrm{tCO}_{2} \mathbf{e q}\right)$ & 0,9830 & 0,5551 & 2,1167 & 0,2866 & 0,7905 & 1,0909 & 0,5587 & 0,3408 & 0,2139 & 0,0099 \\
\hline TRAMO/SECTION & 51 & 52 & & & & & & & & \\
\hline Emisiones/Emissions $\left(\mathrm{tCO}_{2} \mathrm{eq}\right)$ & 0,0938 & 0,0563 & & & & & & & & \\
\hline
\end{tabular}




\section{Conclusiones}

Bajo esta perspectiva y con la metodología planteada, se pueden obtener datos relativos a la cantidad de GEls imputables al tráfico rodado previsto en un municipio consecuencia de las decisiones urbanísticas. En el caso concreto del término municipal de Villaluenga de la Sagra, con las hipótesis consideradas, la red viaria planeada y las alternativas de transporte público previstas, la cantidad total de GEls imputables al tráfico rodado ascendería a $16.8 \mathrm{tCO}_{2} \mathrm{eq} /$ día. Todo ello suponiendo un desarrollo y una ocupación completa del planeamiento previsto y un total de $\mathbf{1 6 . 0 0 0}$ habitantes a techo de planeamiento.

El método propuesto requiere de la asunción de determinadas hipótesis simplificadoras respecto de diversas variables (especialmente las tasas de generación de tráfico para cada uso y el coeficiente de fricción) que deben particularización en función del lugar de aplicación del método.

Ahora bien, la principal ventaja del método propuesto radica en su carácter ex ante y su facilidad de integración dentro del proceso urbanístico de manera que puedan adoptarse medidas compensatorias vía incorporación de sumideros de $\mathrm{CO}_{2}$, por ejemplo mediante la reserva en el planeamiento urbanístico de superficies para usos forestales evitando de esta forma que el potencial usuario asuma el desembolso requerido para la compensación de als emisiones.

El método aporta además información específica respecto de la malla viaria especificando las emisiones esperadas en cada tramo. Esta información puede incluirse dentro de los modelos de toma de decisiones de planeamiento adoptando soluciones que disminuyan las emisiones de los tramos conflictivos y contribuir a un diseño urbano eficiente y sostenible.

\section{Conclusions}

Under this perspective and with the methodology proposed, one can obtain data of the amount of GHGs attributable to road traffic within a municipality due to urban planning decisions. In the case of the municipality of Villaluenga de la Sagra, with the hypotheses considered, the planned road network and public transport alternatives provided, the total amount of GHGs attributable to road traffic would be of $16.8 \mathrm{tCO}_{2} \mathrm{eq} /$ day. This requires a development and a complete occupation of the planning schedule and a total of $\mathbf{1 6 , 0 0 0}$ inhabitants upon planning.

The proposed method requires the assumption of certain simplifying assumptions regarding several variables (especially the traffic generation rates for each use and the friction coefficient) to be focused in a single way depending on the location of the method.

But the main advantage of the proposed method lies in its ex ante and ease of integration into the urban planning process so that compensatory measures can be taken via incorporation of $\mathrm{CO}_{2}$ sinks, such as through the reserve in the planning of land for urban forest use thus avoiding the potential user to assume the expenditure required to compensate emissions.

The method also provides specific information on the roads network specifying the expected emissions for each way. This information can be included in the decisions planning models by adopting solutions that reduce emissions from conflicting sections and contribute to efficient and sustainable urban design. 


\section{Anexo/Annex}

Tabla A.1. Generación de tráfico en los desarrollos urbanísticos previstos

Table A.1. Generation of traffic in planned urban development

\begin{tabular}{|c|c|c|c|c|}
\hline \multirow{2}{*}{ ÁMBITO/AMBIT } & \multirow{2}{*}{ USO/USE } & \multirow{2}{*}{$\begin{array}{l}\text { EDIFICABILIDAD/BUILDING } \\
\text { (m2 construido/constructed m2) }\end{array}$} & \multicolumn{2}{|c|}{ MOVIMIENTOS DIARIOS/DAILY MOVEMENTS } \\
\hline & & & LIGEROS/LIGHT1 & PESADOS/HEAVY \\
\hline CO1 & Industrial & $49.039,08$ & 3,60 & 54,40 \\
\hline $\mathrm{CO} 2$ & Industrial & $21.125,40$ & 5,80 & 23,20 \\
\hline $\mathrm{CO} 3$ & Residencial/Residential & $129.247,93$ & 445,00 & \\
\hline $\mathrm{CO} 4$ & Residencial/Residential & $91.744,06$ & 316,00 & \\
\hline $\mathrm{CO5}$ & Residencial/Residential & $227.238,30$ & 783,00 & \\
\hline $\mathrm{CO6}$ & Residencial/Residential & $12.185,13$ & 42,00 & \\
\hline PE1 & Residencial/Residential & $63.501,17$ & 219,00 & \\
\hline SO1 & Residencial/Residential & $20.578,46$ & 70,00 & \\
\hline SO2 & Residencial/Residential & $220.789,22$ & 761,00 & \\
\hline SO3 & Residencial/Residential & $57.880,29$ & 199,00 & \\
\hline SO5 & Industrial & $240.552,03$ & 67,20 & 268,80 \\
\hline SO6 & Industrial & $244.592,67$ & 68,40 & 273,60 \\
\hline SO7 & Industrial & $532.271,47$ & 149,00 & 596,00 \\
\hline SO8 & Industrial & $331.931,91$ & 92,80 & 371,20 \\
\hline SO9 & Residencial/Residential & $344.744,83$ & $1.189,00$ & \\
\hline SO10 & Residencial/Residential & $240.767,51$ & 830,00 & \\
\hline SO11 & Residencial/Residential & $91.044,33$ & 314,00 & \\
\hline SO12 & Residencial/Residential & $14.170,76$ & 48,00 & \\
\hline SO13 & Residencial/Residential & $83.035,06$ & 286,00 & \\
\hline SO14 & Residencial/Residential & $95.524,05$ & 329,00 & \\
\hline CPE1 & Residencial/Residential & $8.474,65$ & 29,00 & \\
\hline CPE2 & Residencial/Residential & $5.274,39$ & 18,00 & \\
\hline CPE3 & Equipamientos/Equipment & $5.603,71$ & 186,00 & \\
\hline CPE4 & Residencial/Residential & $4.011,66$ & 13,00 & \\
\hline CUA1 & Residencial/Residential & $4.962,22$ & 17,00 & \\
\hline CUA2 & Residencial/Residential & $2.496,65$ & 8,00 & \\
\hline CUA3 & Residencial/Residential & $3.454,84$ & 11,00 & \\
\hline CUA4 & Residencial/Residential & $15.536,98$ & 53,00 & \\
\hline CUA5 & Residencial/Residential & $4.227,75$ & 14,00 & \\
\hline CUA6 & Residencial/Residential & $12.615,11$ & 43,00 & \\
\hline CUA7 & Residencial/Residential & $9.661,80$ & 33,00 & \\
\hline CUA8 & Residencial/Residential & $2.615,48$ & 9,00 & \\
\hline CUA9 & Residencial/Residential & $9.074,45$ & 31,00 & \\
\hline CUA10 & Industrial & $39.226,18$ & 10,80 & 43,20 \\
\hline CPE6 & Comercial & $17.716,80$ & 59,50 & 10,50 \\
\hline CUA11 & Industrial & $33.017,13$ & 9,20 & 36,80 \\
\hline CUA12 & Industrial & $10.453,57$ & 2,80 & 11,20 \\
\hline
\end{tabular}


Sergio Zubelzu Mínguez, Alfonso López Díaz, Miguel Ángel Gutiérrez García, Fernando Blanco Silva

Tabla A.2. Coeficientes de reparto de los municipios del entorno

Table A.2. Distribution coefficient of the surrounding municipalities

\begin{tabular}{|c|c|}
\hline Municipios/Municipalities & Coeficiente de reparto/Distribution coefficient (rj) \\
\hline Ajofrín & $\mathbf{0 , 0 7 \%}$ \\
\hline Alameda de la Sagra & $2,16 \%$ \\
\hline Añover de Tajo & $0,67 \%$ \\
\hline Argés & $0,13 \%$ \\
\hline Bargas & $0,74 \%$ \\
\hline Camarena & $0,22 \%$ \\
\hline Casarrubios del Monte & $1,24 \%$ \\
\hline Cedillo del Condado & $0,72 \%$ \\
\hline Chozas de Canales & $0,29 \%$ \\
\hline Cobeja & $1,80 \%$ \\
\hline Cobisa & $0,06 \%$ \\
\hline Lominchar & $0,31 \%$ \\
\hline Magán & $2,10 \%$ \\
\hline Méntrida & $0,04 \%$ \\
\hline Mocejón & $0,88 \%$ \\
\hline Nambroca & $0,36 \%$ \\
\hline Ocaña & $0,06 \%$ \\
\hline Olías del Rey & $0,25 \%$ \\
\hline Palomeque & $0,03 \%$ \\
\hline Pantoja & $1,12 \%$ \\
\hline Recas & $0,13 \%$ \\
\hline Santa Cruz del Retamar & $0,20 \%$ \\
\hline Seseña & $0,33 \%$ \\
\hline Sonseca & $0,06 \%$ \\
\hline Talavera de la Reina & $0,72 \%$ \\
\hline Toledo & $6,11 \%$ \\
\hline Ugena & $0,60 \%$ \\
\hline Valmojado & $0,12 \%$ \\
\hline Villaseca de la Sagra & $0,26 \%$ \\
\hline Viso de San Juan & $2,54 \%$ \\
\hline Yébenes & $7,95 \%$ \\
\hline Yuncler & $0,10 \%$ \\
\hline Yuncos & $1,32 \%$ \\
\hline Acebeda & $0,05 \%$ \\
\hline Alcorcón & $2,78 \%$ \\
\hline Aranjuez & $0,85 \%$ \\
\hline Arganda del Rey & $0,62 \%$ \\
\hline Arroyomolinos & $0,20 \%$ \\
\hline Batres & $0,03 \%$ \\
\hline Casarrubuelos & $0,05 \%$ \\
\hline Ciempozuelos & $0,39 \%$ \\
\hline Cubas de la Sagra & $0,15 \%$ \\
\hline Fuenlabrada & $4,45 \%$ \\
\hline Getafe & $3,57 \%$ \\
\hline Griñón & $0,44 \%$ \\
\hline Humanes de Madrid & $1,18 \%$ \\
\hline Leganés & $3,41 \%$ \\
\hline Madrid & $37,52 \%$ \\
\hline Moraleja de Enmedio & $0,15 \%$ \\
\hline Móstoles & $3,41 \%$ \\
\hline Navalcarnero & $0,39 \%$ \\
\hline Parla & $3,17 \%$ \\
\hline Pinto & $1,04 \%$ \\
\hline San Martín de la Vega & $0,26 \%$ \\
\hline Serranillos del Valle & $0,12 \%$ \\
\hline Torrejón de Velasco & $0,20 \%$ \\
\hline Torrejón de la Calzada & $0,35 \%$ \\
\hline Valdemoro & $1,51 \%$ \\
\hline Villamanta & $0,03 \%$ \\
\hline
\end{tabular}


Tabla A.3. Reparto de movimientos entre infraestructuras

Tabla A.3. Infrastructure sharing between movements

\begin{tabular}{|c|c|c|c|c|c|}
\hline Municipios/Municipalities & A-42 & N-401 & CM-9050 & TO-4511 & AP-41 \\
\hline Ajofrín & $84,00 \%$ & $16,00 \%$ & & & \\
\hline Alameda de la Sagra & & & & $100,00 \%$ & \\
\hline Añover de Tajo & & & & $100,00 \%$ & \\
\hline Argés & $88,00 \%$ & $12,00 \%$ & & & \\
\hline Bargas & $88,00 \%$ & $12,00 \%$ & & & \\
\hline Camarena & $88,00 \%$ & & $12,00 \%$ & & \\
\hline Casarrubios del Monte & $88,00 \%$ & & $12,00 \%$ & & \\
\hline Cedillo del Condado & $88,00 \%$ & & $12,00 \%$ & & \\
\hline Chozas de Canales & $88,00 \%$ & & $12,00 \%$ & & \\
\hline Cobeja & & & & $100,00 \%$ & \\
\hline Cobisa & $84,00 \%$ & $16,00 \%$ & & & \\
\hline Lominchar & $88,00 \%$ & & $12,00 \%$ & & \\
\hline Magán & $84,00 \%$ & $16,00 \%$ & & & \\
\hline Méntrida & $89,00 \%$ & & $5,50 \%$ & & $5,50 \%$ \\
\hline Mocejón & $88,00 \%$ & & $12,00 \%$ & & \\
\hline Nambroca & $88,00 \%$ & & $12,00 \%$ & & \\
\hline Ocaña & $89,00 \%$ & & $5,50 \%$ & & $5,50 \%$ \\
\hline Olías del Rey & $84,00 \%$ & $16,00 \%$ & & & \\
\hline Palomeque & $88,00 \%$ & & $12,00 \%$ & & \\
\hline Pantoja & & & & $100,00 \%$ & \\
\hline Recas & $100,00 \%$ & & & & \\
\hline Santa Cruz del Retamar & $88,00 \%$ & & $12,00 \%$ & & \\
\hline Seseña & $12,00 \%$ & & & $88,00 \%$ & \\
\hline Sonseca & $84,00 \%$ & $16,00 \%$ & & & \\
\hline Talavera de la Reina & $88,00 \%$ & & & & $12,00 \%$ \\
\hline Toledo & $89,00 \%$ & $5,50 \%$ & & & $5,50 \%$ \\
\hline Ugena & $100,00 \%$ & & & & \\
\hline Valmojado & $100,00 \%$ & & & & \\
\hline Villaseca de la Sagra & $12,00 \%$ & & $88,00 \%$ & & \\
\hline Viso de San Juan & $100,00 \%$ & & & & \\
\hline Yébenes & $88,00 \%$ & $12,00 \%$ & & & \\
\hline Yuncler & $100,00 \%$ & & & & \\
\hline Yuncos & $100,00 \%$ & & & & \\
\hline Acebeda & $88,00 \%$ & & & & $12,00 \%$ \\
\hline Alcorcón & $88,00 \%$ & & & & $12,00 \%$ \\
\hline Aranjuez & $88,00 \%$ & & & $12,00 \%$ & \\
\hline Arganda del Rey & $88,00 \%$ & & & $12,00 \%$ & \\
\hline Arroyomolinos & $88,00 \%$ & & & & $12,00 \%$ \\
\hline Batres & $88,00 \%$ & & & & $12,00 \%$ \\
\hline Casarrubuelos & $100,00 \%$ & & & & \\
\hline Ciempozuelos & $88,00 \%$ & & & $12,00 \%$ & \\
\hline Cubas de la Sagra & $100,00 \%$ & & & & \\
\hline Fuenlabrada & $88,00 \%$ & & & & $12,00 \%$ \\
\hline Getafe & $88,00 \%$ & & & & $12,00 \%$ \\
\hline Griñón & $100,00 \%$ & & & & \\
\hline Humanes de Madrid & $100,00 \%$ & & & & \\
\hline Leganés & $88,00 \%$ & & & & $12,00 \%$ \\
\hline Madrid & $88,00 \%$ & & & & $12,00 \%$ \\
\hline Moraleja de Enmedio & $88,00 \%$ & & & & $12,00 \%$ \\
\hline Móstoles & $88,00 \%$ & & & & $12,00 \%$ \\
\hline Navalcarnero & $88,00 \%$ & & & & $12,00 \%$ \\
\hline Parla & $100,00 \%$ & & & & \\
\hline Pinto & $100,00 \%$ & & & & \\
\hline San Martín de la Vega & $88,00 \%$ & & & & $12,00 \%$ \\
\hline Serranillos del Valle & $100,00 \%$ & & & & \\
\hline Torrejón de Velasco & $100,00 \%$ & & & & \\
\hline Torrejón de la Calzada & $100,00 \%$ & & & & \\
\hline Valdemoro & $88,00 \%$ & & & & $12,00 \%$ \\
\hline Villamanta & $88,00 \%$ & & & & $12,00 \%$ \\
\hline
\end{tabular}


Sergio Zubelzu Mínguez, Alfonso López Díaz, Miguel Ángel Gutiérrez García, Fernando Blanco Silva

Tabla A.4. Coeficientes de reparto particularizados

Tabla A.4. Specializing distribution coefficients

\begin{tabular}{|c|c|c|c|c|c|}
\hline Municipios/Municipalities & $\mathrm{A}-42$ & $\mathrm{~N}-401$ & CM-9050 & TO-4511 & AP-41 \\
\hline Ajofrín & $0,06 \%$ & $0,01 \%$ & & & \\
\hline Alameda de la Sagra & & & & $2,16 \%$ & \\
\hline Añover de Tajo & & & & $0,67 \%$ & \\
\hline Argés & $0,11 \%$ & $0,02 \%$ & & & \\
\hline Bargas & $0,65 \%$ & $0,09 \%$ & & & \\
\hline Camarena & $0,20 \%$ & & $0,03 \%$ & & \\
\hline Casarrubios del Monte & $1,09 \%$ & & $0,15 \%$ & & \\
\hline Cedillo del Condado & $0,63 \%$ & & $0,09 \%$ & & \\
\hline Chozas de Canales & $0,25 \%$ & & $0,03 \%$ & & \\
\hline Cobeja & & & & $1,80 \%$ & \\
\hline Cobisa & $0,05 \%$ & $\mathbf{0 , 0 1 \%}$ & & & \\
\hline Lominchar & $0,27 \%$ & & $0,04 \%$ & & \\
\hline Magán & $1,76 \%$ & $\mathbf{0 , 3 4} \%$ & & & \\
\hline Méntrida & $0,03 \%$ & & & & \\
\hline Mocejón & $0,77 \%$ & & $0,11 \%$ & & \\
\hline Nambroca & $0,32 \%$ & & $0,04 \%$ & & \\
\hline Ocaña & $0,05 \%$ & & & & \\
\hline Olías del Rey & $0,21 \%$ & & & & \\
\hline Palomeque & $0,03 \%$ & & & & \\
\hline Pantoja & & & & $1,12 \%$ & \\
\hline Recas & $0,13 \%$ & & & & \\
\hline Santa Cruz del Retamar & $0,18 \%$ & & $0,02 \%$ & & \\
\hline Seseña & $0,04 \%$ & & & $0,29 \%$ & \\
\hline Sonseca & $0,05 \%$ & $0,01 \%$ & & & \\
\hline Talavera de la Reina & $0,64 \%$ & & & & $0,09 \%$ \\
\hline TOLEDO & $5,44 \%$ & $0,34 \%$ & & & $0,34 \%$ \\
\hline Ugena & $0,60 \%$ & & & & \\
\hline Valmojado & $0,12 \%$ & & & & \\
\hline Villaseca de la Sagra & $0,03 \%$ & & $0,23 \%$ & & \\
\hline Viso de San Juan & $2,54 \%$ & & & & \\
\hline Yébenes & $7,00 \%$ & $0,95 \%$ & & & \\
\hline Yuncler & $0,10 \%$ & & & & \\
\hline Yuncos & $1,32 \%$ & & & & \\
\hline Acebeda & $0,05 \%$ & & & & $0,01 \%$ \\
\hline Alcorcón & $2,45 \%$ & & & & $0,33 \%$ \\
\hline Aranjuez & $0,75 \%$ & & & $0,10 \%$ & \\
\hline Arganda del Rey & $0,55 \%$ & & & $0,07 \%$ & \\
\hline Arroyomolinos & $0,18 \%$ & & & & $0,02 \%$ \\
\hline Batres & $0,03 \%$ & & & & \\
\hline Casarrubuelos & $0,05 \%$ & & & & \\
\hline Ciempozuelos & $0,34 \%$ & & & $0,05 \%$ & \\
\hline Cubas de la Sagra & $0,15 \%$ & & & & \\
\hline Fuenlabrada & $3,91 \%$ & & & & $0,53 \%$ \\
\hline Getafe & $3,15 \%$ & & & & $0,43 \%$ \\
\hline Griñón & $0,44 \%$ & & & & \\
\hline Humanes de Madrid & $1,18 \%$ & & & & \\
\hline Leganés & $3,00 \%$ & & & & $0,41 \%$ \\
\hline Madrid & $33,01 \%$ & & & & $4,50 \%$ \\
\hline Moraleja de Enmedio & $0,13 \%$ & & & & $0,02 \%$ \\
\hline Móstoles & $3,00 \%$ & & & & $0,41 \%$ \\
\hline Navalcarnero & $0.34 \%$ & & & & $0.05 \%$ \\
\hline Parla & $3,17 \%$ & & & & \\
\hline Pinto & $1,04 \%$ & & & & \\
\hline San Martín de la Vega & $0,23 \%$ & & & & $0,03 \%$ \\
\hline Serranillos del Valle & $0,12 \%$ & & & & \\
\hline Torrejón de Velasco & $0,20 \%$ & & & & \\
\hline Torrejón de la Calzada & $0,35 \%$ & & & & \\
\hline Valdemoro & $1,33 \%$ & & & & $0,18 \%$ \\
\hline Villamanta & $0,03 \%$ & & & & \\
\hline
\end{tabular}




\section{Referencias / References}

Correa G. (2010), Transporte y Ciudad [versión electrónica]. Eure, 36 (107), 133-137.

DEFRA (2009), 2009 Guidelines to Defra/DECC's GHG Conversion Factors for Company Reporting. 30 de septiembre de 2009. Department of Energy and Climate Change (DECC), Department for Environment, Food and Rural Affairs (DEFRA). http://archive.defra.gov.uk/environment/business/reporting/pdf/20090928-guidelines-ghg-conversion-factors.pdf Intergovernmental Panel on Climate Change (IPCC) (2003), Buendía L, Gytarsky M, Hiraishi T, Krug T, Kruger D, Penman J, Pipatti R, Miwa K, Ngara T, Tanabe K, Wagner F. Good Practice Guidance for Land Use, Land-Use Change and Forestry. Institute for Global Environmental Strategies

Intergovernmental Panel on Climate Change (IPCC) (2006), Buendía L., Eggelston S., Miwa K, Ngara T, Tanabe K. IPCC 2006,2006 IPCC Guidelines for National Greenhouse Gas Inventories. Institute for Global Environmental Strategies

Ortúzar J. y Román C. (2003), El problema de modelación de demanda desde una perspectiva desagregada: el caso del transporte [versión electrónica]. Eure, XXIX (88), 149-171.

Transportation Research Board, National Academy of Science (2000), Highway Capacity Manual

Willumsen L. (1985), Modelos simplificados de transporte urbano [versión electrónica]. Eure, XII (33), 49-64 World Resources Institute (2008), GHG Protocol tool for mobile combustión. Versión 2.0 